DOI https://doi.org/10.18551/rjoas.2018-02.11

\title{
THE INFLUENCE OF HEDONIC SHOPPING MOTIVATION TO THE IMPULSE BUYING OF ONLINE-SHOPPING CONSUMER ON INSTAGRAM
}

\author{
Asnawati ${ }^{\star}$, Wahyuni Sri \\ Faculty of Economics and Business, University of Mulawarman, Indonesia \\ *E-mail: asnawati@feb.unmul.ac.id
}

\begin{abstract}
This research aims to know the influence of Adventure Shopping, Relaxation Shopping, Value Shopping, Social Shopping and Idea Shopping variables to the variable of Impulse Buying of Online-Shopping Consumer on Instagram. The type of the research is explanatory research. The result of $F$-test showed that $F_{\text {count }}(12.829)>F_{\text {table }}(2.669)$ which meant that research variables had influences to the Impulse Buying. With partial correlation value of 0.548, Idea Shopping variable became the dominant factor influencing Impulse Buying on the online-shopping purchase on Instagram.
\end{abstract}

\section{KEY WORDS}

Hedonic shopping, impulse buying, online shopping, Instagram.

Indonesia is an eastern-culture country that has many distinctive characteristics. In spite of that, Indonesia is still relatively easy to get the impact of globalization, both positive and negative impacts. Currently, western cultures are rapidly entering the eastern-culture countries, including Indonesia; it is often settled for a long time and eventually mixed into part of the eastern culture itself. It is due to the lack of individual filter of each Indonesian, so they accept the western cultures directly. Even so, the western culture, which is considered as modern culture, is considered also as in accordance with the ethics and norms of Indonesia.

One culture hereditary and unconsciously survives in Indonesia is consumptive culture. This culture is not considered to be owned by every individual of Indonesia, but at least the majority of civilian people who are settled in urban areas behave this way. In terms of the increased doers, teenagers and young adults (high school students and equivalents, college students, and men / women aged up to 40 years) are the fastest group of age in absorbing consumptive culture. This consumptive pattern occurs in nearly all levels of people, with varying levels. Mostly, teenagers are easily affected by the excessive consumption patterns (Loudon and Bitta, 1993).

In this type of consumption (hedonic shopping), consumers prefer interesting experience, fantasy, entertainment, and sensory stimulation from the use of the purchased products or services. According to Arnold and Reynold (in Utami, 2010: 49), hedonic shopping motivation consists of five main dimensions:

- Adventure Shopping: shopping activity is an adventure activity in which it can raise motivation and gain the consumer's own world by doing the shopping.

- Gratification/ relaxation shopping: shopping activity is one alternative to cope with stress, to treat an uncomfortable mood, as well as a means to deal with the problems and fatigue.

- Value Shopping: shopping activity is performed when the consumers look for shopping spots offering discounts.

- Social Shopping: mostly, consumers believe that shopping pleasure will be gained when they spend time together with family or friends, as a social activity. By doing shopping together with family or friends, they get a lot of information about the product to be purchased.

- Idea Shopping: consumers do the shopping to keep up with the latest trend of the fashion model and to see new products and innovations.

In this research, hedonic pattern becomes a topic related to online purchases. Hedonic shopping motivations are similar to utilitarian shopping pattern; the purchasing decisions 
related to hedonistic spending, such as having fun experience, entertainment, and fantasy. The value of hedonic shopping refers to the sense of pleasure and fun that consumers receive from all purchasing experiences associated with shopping activities. In the hedonic shopping, the consumers are not planning the product to be purchased and mostly consumers make purchases due to the products that is considered as interesting, (Kasser and Kanner, 2004).

Based on the description that has been discussed above, the main research problem is how the influence of adventure shopping, relaxation shopping, value shopping, social shopping, and idea shopping to the impulse buying of online-shopping consumer on Instagram. The result of the research is expected to obtain the influence of adventure shopping, relaxation shopping, value shopping, social shopping, and idea shopping to the impulse buying of online-shopping consumer on Instagram.

\section{LITERATURE REVIEW}

Marketing. Marketing is identifying and meeting human and social needs. The appropriate and brief definition of marketing is to meet the needs in a profitable way, (Wilson et al., 2012). The purpose of marketing is to meet the target customers and satisfy the needs and desires. It is obvious because the satisfied consumers will come to buy or use goods or services that are offered by marketers, (Jain and Haley, 2009). Therefore, better understanding of consumer action pattern on goods or services will be vital. Sufficient information on consumer behavior will then be considered as important (Kotler and Keller, 2009: 5).

Marketing is an overall system of business activities that is aimed at planning, pricing, promoting and distributing goods and services that satisfy the needs of both existing and potential buyers. (William J. Stanton quoted by Basu and Hani, 2000: 4)

Description of Marketing Management. Marketing management is an activity of analyzing, planning, implementing and supervising all activities (programs) in order to obtain a favorable exchange rate to the target buyers in order to achieve organizational goals, (Kotler and Armstrong, 1999). Another opinion mentions that marketing management is planning, directing and supervising all marketing activities of the company or part of the company (Anderson et al., 2009). Marketing management is a process of improving the efficiency and effectiveness of marketing activities that are performed by individuals or companies; quoted from Alma (2004).

Hedonic Shopping Motivation. According Utami (2010), hedonic motivation is consumer's motivation for shopping because it has pleasure that makes the consumers pay no attention to the benefits of the purchased products.

- Social experience. Shopping centers have become a gathering place for various groups of people. Purchases that have been made will be an experience. Experience will create consumer's habit or attitude about retail. Large number of people coming from the suburban or certain areas, have no place to spend their free time so they come to the shopping center to spend their time to socialize with others. They socialize to get an appreciation from others. Sometimes, they pursue social status. Measurement that is used to get social status or social class is occupation, income and education level.

- Having the same interest. A store offers special goods to meet the needs of the community in order to generate an interest of communication. It happens because they are always adaptive to the advertising or promotional activities that are performed by supermarkets or hypermarkets. They are interested in the activities performed by modern retailers. The stimuli of promotion, price, and other marketing strategies are intended to influence consumers. Moreover, retail information is easy to obtain with no any sacrifices. Retail information, including price, the completeness of the product and the closest store to the consumer, is advertised in print and electronic media. Retail management periodically publishes shopping magazines that are distributed to consumers as well as for promotional purposes. 
- Individual attractiveness. Shopping center is built for a place to gather. For example, teenagers use the shopping center as a place to hang out or do browsing activities, take for a walk or see a new product. Shopping centers can be used as a place to hang out and seek information.

- Instant status. Each salesperson knows that some people feel or enjoy the services provided even if they do not make a purchase. In addition, shopping activities make a person participate in groups such as family, club or organization. The position of a person in a group is determined by the status. People choose products that can raise their status in the community.

- Seeking sensation. Some people feel proud if they know more about the place of trade. It is an impulse or sensation for them.

Impulse Buying. Impulsive buying is defined as unplanned, sudden, and spontaneous gestures to purchase something, which is less cautious to the evaluation of the product or the consequences of subsequent purchases, (Paramitha et al., 2014). Impulse buying is classified into four groups: 1) Pure Impulse Buying occurs due to the emotional outflow of the consumer so that purchase of products is outside the purchase habits, 2) Reminder Impulse Buying occurs when the consumer suddenly remember to purchase certain product, 3) Suggestion Impulse Buying occurs when the consumer looks at the product, looks at the usage instruction, and then decides to make a purchase, 4) Planned Impulse Buying is a purchase that occurs when consumers buy products based on special prices and certain products, (Srivastava and Kumar, 2013)

Impulse Buying Measurements. According to Rook and Fisher, (1995) about Impulse Buying Measurements, it is the tendency of consumers to buy spontaneously, unconsciously, abruptly and automatically. Impulse buying focuses on the appeal of sentiment and passion to buy. It deals with one's emotions. The attraction is related to the goods that a particular store has to offer, so they are interested and have a passion to buy it.

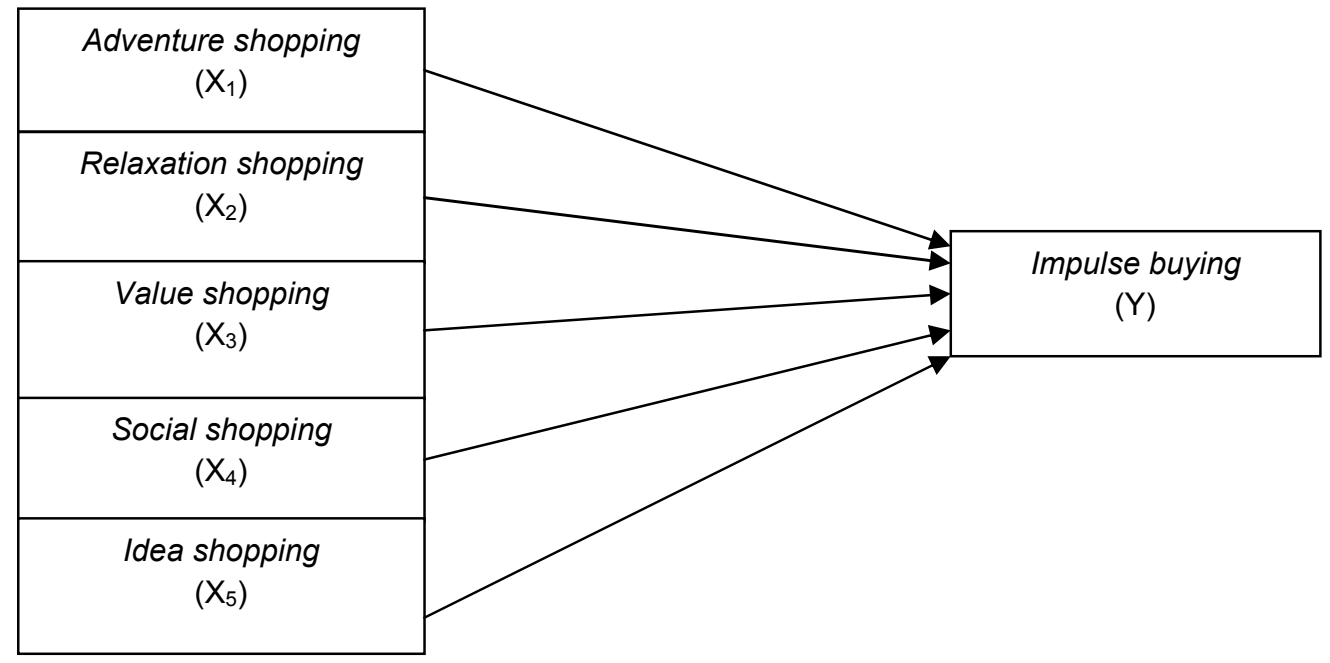

Figure 1 - Conceptual Research Framework

\section{Research Hypothesis:}

$\mathrm{H} 1$ : Adventure shopping has positive and significant impact to impulse buying.

$\mathrm{H} 2$ : Relaxation shopping has positive and significant impact to impulse buying.

H3: Value shopping has positive and significant impact to impulse buying.

$\mathrm{H} 4$ : Social shopping has positive and significant impact to impulse buying.

H5: Idea shopping has positive and significant impact to impulse buying.

\section{METHODS OF RESEARCH}

The type of the research is explanatory research. Explanatory research is a research aiming to test a theory or hypothesis to strengthen or reject a theory or hypothesis of the 
previous research results. Measurement, conducted by the authors in the process of data analyzing was Likert scale. Likert scale is used to measure attitudes, opinions and perceptions of a person or group of people about social phenomena, Ginting and Situmorang, (2008: 121). In this research, the respondent chose one of the answers consisting particular score. Then respondent's score was summed up and it was the total score. Total score was interpreted as respondent's position in Likert scale. The population in this research is unknown but the researcher took the entire population who had made at least two purchases of on various types of online products at online shopping on Instagram. Data sampling technique used in this research is random sampling technique. This research used as many as 109 respondents.

Data Collection Method. In obtaining the data, the data collection process used the following methods:

Library Research. The data collection method is conducted by reading books, articles and magazines that deal directly with the problem under research. Thesis is used as reference from the previous research. In addition, it needs to browse the data through the internet to find articles and journals or data that may help the results of research.

Field Research. The data collection method is conducted by direct way to the object of research to get primary data through by distributing the questionnaires to consumers containing problem under research. Respondents are to respond to the question of how much the influence of a hedonic shopping motivation to the impulse buying of onlineshopping consumers on Instagram.

\section{RESULTS AND DISCUSSION}

Validity Test Results. By comparing the value of Pearson correlation and $r_{\text {table }}$ using $95 \%$ confidence level, $\alpha=30-2=28$ (the number of respondents validity test minus two), the results for $r_{\text {table }}$ was 0.361 . Table 1 shows the results of validity test.

Table 1 - Validity Test Results

\begin{tabular}{ccccc}
\hline Variable & Item & r-count & r-table & Result \\
\hline $\mathrm{X}_{1}$ & $\mathrm{X}_{1.1}$ & 0.739 & \multirow{2}{*}{0.361} & Valid \\
& $\mathrm{X}_{1.2}$ & 0.549 & Valid \\
\hline $\mathrm{X}_{2}$ & $\mathrm{X}_{2.1}$ & 0.622 & 0.361 & Valid \\
& $\mathrm{X}_{2.2}$ & 0.618 & \multirow{2}{*}{0.361} & Valid \\
\hline $\mathrm{X}_{3}$ & $\mathrm{X}_{3.3}$ & 0.1000 & \multirow{2}{*}{0.361} & Valid \\
\hline \multirow{2}{*}{$\mathrm{X}_{4}$} & $\mathrm{X}_{4.1}$ & 0.510 & & Valid \\
& $\mathrm{X}_{4.1}$ & 0.842 & \multirow{2}{*}{0.361} & Valid \\
\hline \multirow{2}{*}{$\mathrm{X}_{5}$} & $\mathrm{X}_{5.1}$ & 0.091 & & Valid \\
& $\mathrm{X}_{5.2}$ & 0.811 & & Valid \\
& $\mathrm{X}_{5.3}$ & 0.489 & \multirow{2}{*}{0.361} & Valid \\
\hline & $\mathrm{Y}_{.1}$ & 0.291 & & Valid \\
$\mathrm{Y}$ & $\mathrm{Y}_{.2}$ & 0.964 & & Valid \\
& $\mathrm{Y}_{.3}$ & 0.447 & & Valid \\
\hline
\end{tabular}

The result of validity test was obtained by using SPSS program by comparing Pearson Correlation value (product moment correlation) with $r_{\text {table }}$ value using $95 \%$ confidence level, $\alpha$ $=5 \%$, dfl $=6-1=5$ (number of independent and dependent variable minus 1 ) and df2 $=n k-1$ or $109-5-1=103$ ( $n$ is the number of samples and $k$ is the number of independent variables); the result for $r_{\text {table }}$ was 0.361 . Determining an item is considered as valid if the correlation of each factor is positive and bigger than 0.361 then the factor is a strong construct with sig < alpha $(0.05)$ and vice versa. If the correlation of each factor is negative or less than 0.361 with Sig > alpha (0.05) then the question is considered as invalid.

Reliability Test Results. Measurement of instrument reliability was conducted using statistical test of Cronbach's alpha ( $\alpha)$. It is reliable if it gives the Croncbach's alpha value ( $\alpha)$ 
$>0.60$. If the correlation coefficient is greater than the crisis value $(0.60)$ then the measurement is reliable and vice versa. Table 2 shows reliability test results.

Table 2 - Reliability Test Results

\begin{tabular}{ccc}
\hline Variable & Cronbach's Alpha Value & Crisis Value \\
\hline$\left(X_{1}\right)$ & 0.763 & 0.60 \\
$\left(X_{2}\right)$ & 0.726 & 0.60 \\
$\left(X_{3}\right)$ & 0.1000 & 0.60 \\
$\left(X_{4}\right)$ & 0.801 & 0.60 \\
$\left(X_{5}\right)$ & 0.600 & 0.60 \\
$(Y)$ & 0.661 & 0.60 \\
\hline
\end{tabular}

Criteria for an instrument to be reliable by using this technique, it is if Cronbach alpha $>$ 0.6 but when Cronbach alpha $<0.6$, it shows the absence of consistency. The research results of the reliability of independent and dependent variables in this research showed that Cronbach alpha is bigger than 0.6 so it can be concluded that all independent variables in this research are reliable.

Multiple Linear Regression Analysis. Based on the results of multiple linear regression calculations by using SPSS 17.0, the data were obtained, as can be seen in Table 3.

Table 3 - Multiple Regression Analysis Results

\begin{tabular}{ccccc}
\hline Independent Variable & Regression Coefficient & t-count & Sig & $\mathrm{R}$ \\
\hline Constanta & -22.093 & 3.335 & 0,001 & - \\
Adventure shopping & 0.1579 & 3.149 & 0.002 & 0.296 \\
Relaxation shopping & 0.1466 & 3.890 & 0.005 & 0.274 \\
Value shopping & 0.1729 & 2.142 & 0.035 & 0.206 \\
Social shopping & 0.254 & 2.548 & 0.020 & 0.053 \\
Idea shopping & 0.1659 & 6.641 & 0.000 & 0.548 \\
Multiple R = 0.619 & F-count $=12.829$ & t-table $=1.984$ & \\
\hline R Square $=0,384$ Significance Level $=0,000$ & & & & \\
D-Watson = 679 & &
\end{tabular}

From the table 4.3 above, by the value of $\alpha=5 \%(0.05)$, multiple linear regression equation is obtained as follows:

$$
Y=-22.093+0.1 .579 X_{1}+0.1 .466 X_{2}+0.1 .729 X_{3}+0.254 X_{4}+0.1 .659 X_{5}
$$

Multicollinearity Test Results. Based on the analysis results that have been processed by using SPSS 17.0 program, multicollinearity test with the test value of tolerance and VIF is as can be seen in Table 4.

Table 4 - Tolerance and VIF

\begin{tabular}{cccc}
\hline Independent Variable & Tolerance & VIF & Crisis Value \\
\hline Adventure shopping $\left(X_{1}\right)$ & 981 & 1.019 & 5 \\
Relaxation shopping $\left(X_{2}\right)$ & 966 & 1.035 & 5 \\
Value shopping $\left(X_{3}\right)$ & 951 & 1.052 & 5 \\
Social shopping $\left(X_{4}\right)$ & 997 & 1.003 & 5 \\
Idea shopping $\left(X_{5}\right)$ & 995 & 1.005 & 5 \\
\hline
\end{tabular}

Based on the table 4 above, it shows that the values of tolerance and VIF of each variable are less than five. It can be concluded that in this research multicollinearity does not occur to independent variable in regression model.

Heteroscedasticity Test Results. In this research heteroscedasticity test was conducted by Park testing. It was conducted by looking at beta coefficients on each variable: Adventure Shopping $\left(X_{1}\right)$ of 0.1579 , Relaxation Shopping $\left(X_{2}\right)$ of 0.1466 , Value Shopping $\left(X_{3}\right)$ of 0.1729 , Social Shopping $\left(X_{4}\right)$ of 0.254 and Idea Shopping $\left(X_{5}\right)$ of 0.659 . The value of each variable is more than significant level of 0.05 or $5 \%$ which means there is no heteroscedasticity between variables in the regression model. 
Table 5 - Heteroscedasticity Test with Beta Coefficients

\begin{tabular}{cccc}
\hline Independent Variable & $\beta$ Coefficient & Sig. Value & Description \\
\hline Adventure Shopping $\left(X_{1}\right)$ & 0.1579 & 0.05 & Heteroscedasticity does not occur \\
Relaxation Shopping $\left(X_{2}\right)$ & 0.1466 & 0.05 & Heteroscedasticity does not occur \\
Value Shopping $\left(\mathrm{X}_{3}\right)$ & 0.1729 & 0.05 & Heteroscedasticity does not occur \\
Social Shopping $\left(\mathrm{X}_{4}\right)$ & 0.254 & 0.05 & Heteroscedasticity does not occur \\
Idea Shopping $\left(\mathrm{X}_{5}\right)$ & 0.1659 & 0.05 & Heteroscedasticity does not occur \\
\hline
\end{tabular}

Autocolliniearity Test Results. Based on the output, Durbin Watson (DW) $=673$. If DW is 1.55-2.46, it is considered that autocolliniearity does not occur in this regression model.

Table 6 - Durbin Watson

\begin{tabular}{|c|c|}
\hline Model & Durbin Watson \\
\hline 1 & 673 \\
\hline
\end{tabular}

\section{DISCUSSION OF RESULTS}

Based on the results of multiple linear regression equation, $R$ value was obtained 0.619. It meant that contribution of independent variable of Adventure Shopping $\left(X_{1}\right)$, Relaxation Shopping $\left(X_{2}\right)$, Value Shopping $\left(X_{3}\right)$, Social Shopping $\left(X_{4}\right)$ and Idea Shopping $\left(X_{5}\right)$ to the dependent variable of Impulse Buying $(\mathrm{Y})$ is $61.9 \%$. It showed a very close relationship and multiple determination coefficient $\left(R^{2}\right)$ of $38.4 \%$ in which showed the influence of independent variable variations of Adventure Shopping $\left(X_{1}\right)$, Relaxation Shopping $\left(X_{2}\right)$, Value Shopping $\left(X_{3}\right)$, Social Shopping $\left(X_{4}\right)$ and Idea Shopping $\left(X_{5}\right)$ to the dependent variable of Impulse Buying $(Y)$ while the remaining were variables not under research $61 \%$.

To see the significance of all independent variables of Adventure Shopping $\left(X_{1}\right)$, Relaxation Shopping $\left(X_{2}\right)$, Value Shopping $\left(X_{3}\right)$, Social Shopping $\left(X_{4}\right)$ and Idea Shopping $\left(X_{5}\right)$ to the dependent variable of Impulse Buying $(Y)$ on online-shopping consumer in Instagram, it can be seen from ANOVA table where the value of $F_{\text {count }}$ equal to 12.829 bigger than $F_{\text {table }}$ equal to 2.699 with the significance of 0.000 smaller than the significant level of 0.005 . This shows Adventure Shopping $\left(X_{1}\right)$, Relaxation Shopping $\left(X_{2}\right)$, Value Shopping $\left(X_{3}\right)$, Social Shopping $\left(X_{4}\right)$ and Idea Shopping $\left(X_{5}\right)$ to the dependent variable of Impulse Buying $(Y)$ has significant influence on the change of dependent variable of Impulse Buying $(Y)$ on onlineshopping consumer in Instagram; it was supported by the first hypothesis that independent variables of Adventure Shopping $\left(X_{1}\right)$, Relaxation Shopping $\left(X_{2}\right)$, Value Shopping $\left(X_{3}\right)$, Social Shopping $\left(X_{4}\right)$ and Idea Shopping $\left(X_{5}\right)$ had influences to the dependent variable of Impulse Buying $(Y)$ on online-shopping consumer in Instagram.

Simultaneous Analysis and Discussion of the Test (F-test). Simultaneous or joint test (F-test) was conducted to know the significant influence of Adventure Shopping $\left(\mathrm{X}_{1}\right)$, Relaxation Shopping $\left(X_{2}\right)$, Value Shopping $\left(X_{3}\right)$, Social Shopping $\left(X_{4}\right)$ and Idea Shopping $\left(X_{5}\right)$ to Impulse Buying (Y). F-test was conducted by comparing the $F_{\text {count }}$ and $F_{\text {table. The }}$ Thest was conducted at the level of significant $95 \%, \alpha=0.05$ with the degree of freedom (df) $n-k-1=109-5-1=103$.

Table 7 - Simultaneous Test Results (F-test)

\begin{tabular}{cccccc}
\hline Correlation Coefficient $(R)$ & Determination Coefficient $\left(R^{2}\right)$ & $F_{\text {count }}$ & $F_{\text {table }}$ & Sig. & Description \\
\hline 0.619 & 0.384 & 12.829 & 2.669 & 0.000 & Significant \\
\hline
\end{tabular}

Based on the summary of multiple linear regression results in the table, it showed that $F_{\text {count }}$ is 12.829 and $F_{\text {table }}$ distribution had level of error $5 \% 2.669$. It meant that $F_{\text {count }}>F_{\text {table }}$ $(12.829>2.669)$. It showed that Adventure Shopping $\left(X_{1}\right)$, Relaxation Shopping $\left(X_{2}\right)$, Value Shopping $\left(X_{3}\right)$, Social Shopping $\left(X_{4}\right)$ and Idea Shopping $\left(X_{5}\right)$ variable simultaneously had influences to Impulse Buying $(Y)$ variable. Therefore, the authors concluded that the first, second, and third hypothesis of the research is proven and acceptable. 
Determination Coefficient $\left(R^{2}\right)$. Based on the summary of multiple linear regression results in table 4.3 , it showed the value of $R=0.619$. It meant that there was positive and strong relationship between the influence of Adventure Shopping $\left(X_{1}\right)$, Relaxation Shopping $\left(X_{2}\right)$, Value Shopping $\left(X_{3}\right)$, Social Shopping $\left(X_{4}\right)$ and Idea Shopping $\left(X_{5}\right)$ and Impulse Buying $(Y)$. It had correlation of $61.9 \%$. From these results, coefficient determination $\left(R^{2}\right)$ value was $38.4 \%$ of the dependent variable: Impulse Buying $(\mathrm{Y})$. The remaining $61.6 \%$ was influenced by other factors not under research.

Partial Test (t-test). Partial test aims to see the extent of the influence separately from each independent variable $(X)$ to dependent variable $(Y)$ based on the results of multiple linear regressions that are conducted by comparing the value of $t_{\text {count }}$ and $t_{\text {table; }}$; it can be concluded that the variable had a significant influence.

Table 8 - Partial Test Results (t-test)

\begin{tabular}{ccccccc}
\hline Variables & Regression Coefficient & Correlation Coefficient & $t_{\text {count }}$ & $t_{\text {table }}$ & Sig. & Description \\
\hline Constant & -22.093 & & & & & \\
Adventure Shopping & 0.246 & 0.244 & 3.149 & 2.009 & 0.001 & Significant \\
Relaxation Shopping & 0.227 & 0.224 & 2.890 & 2.009 & 0.005 & Significant \\
Value Shopping & 0.170 & 0.166 & 2.142 & 2.009 & 0.027 & Significant \\
Social shopping & 0.254 & 0.042 & 2.548 & 2.009 & 0,020 & Significant \\
Idea Shopping & 0.1 .659 & 0.514 & 6.64 & 2.009 & 0.000 & Significant \\
\hline
\end{tabular}

Adventure Shopping Variable $\left(X_{1}\right)$. The influence of Adventure Shopping $\left(X_{1}\right)$ variable to Impulse Buying of online-shopping consumer on Instagram can be seen on the partial correlation coefficient value of 0.244 . It means that contribution (influence) of Adventure Shopping variable $\left(X_{1}\right)$ to Impulse Buying is $24.4 \%$. The value of $t_{\text {count }}$ for this variable is 3.149 , bigger that the value of $t_{\text {table }}$ of 2.009 . Then, $t_{\text {count }}>t_{\text {table, }}, H_{0}$ is rejected and $H_{1}$ is accepted. In addition, Adventure Shopping $\left(X_{1}\right)$ variable has a significant value of 0.001 smaller than $(\alpha) 0.05$. It shows that Adventure Shopping $\left(X_{1}\right)$ variable has positive and significant influence on Impulse Buying $(Y)$ variable.

Relaxation Shopping Variable $\left(X_{2}\right)$. The influence of Relaxation Shopping $\left(\mathrm{X}_{2}\right)$ variable to Impulse Buying of online-shopping consumer on Instagram can be seen on the partial correlation coefficient value of 0.224 . It means that contribution (influence) of Relaxation Shopping variable $\left(\mathrm{X}_{2}\right)$ to Impulse Buying is $22.4 \%$. The value of $t_{\text {count }}$ for this variable is 2.890 , bigger that the value of $t_{\text {table }}$ of 2.009. Then, $t_{\text {count }}>t_{\text {table }}, H_{0}$ is rejected and $H_{1}$ is accepted. In addition, Relaxation Shopping $\left(X_{2}\right)$ variable has a significant value of 0.005 smaller than $(\alpha)$ 0.05. It shows that Relaxation Shopping $\left(X_{2}\right)$ variable has positive and significant influence on Impulse Buying $(Y)$ variable.

Value Shopping Variable $\left(X_{3}\right)$. The influence of Value Shopping $\left(X_{3}\right)$ variable to Impulse Buying of online-shopping consumer on Instagram can be seen on the partial correlation coefficient value of 0.166 . It means that contribution (influence) of Value Shopping $\left(X_{3}\right)$ to Impulse Buying is $1.66 \%$. The value of $t_{\text {count }}$ for this variable is 2.142 , bigger that the value of $t_{\text {table }}$ of 2.009. Then, $t_{\text {count }}>t_{\text {table }}, H_{0}$ is rejected and $H_{1}$ is accepted. In addition, Value Shopping $\left(X_{3}\right)$ variable has a significant value of 0.027 smaller than $(\alpha) 0.05$. It shows that Value Shopping $\left(\mathrm{X}_{3}\right)$ variable has positive and significant influence on Impulse Buying $(\mathrm{Y})$ variable.

Social Shopping Variable $\left(X_{4}\right)$. The influence of Social Shopping $\left(\mathrm{X}_{4}\right)$ variable to Impulse Buying of online-shopping consumer on Instagram can be seen on the partial correlation coefficient value of 0.042 . It means that contribution (influence) of Social Shopping $\left(\mathrm{X}_{4}\right)$ to Impulse Buying is $0.42 \%$. The value of $t_{\text {count }}$ for this variable is 2.548 , bigger that the value of $t_{\text {table }}$ of 2.009 . Then, $t_{\text {count }}>t_{\text {table }}, H_{0}$ is rejected and $H_{1}$ is accepted. In addition, Social Shopping $\left(X_{4}\right)$ variable has a significant value of 0.020 smaller than $(\alpha) 0.05$. It shows that Social Shopping $\left(X_{4}\right)$ variable has positive and significant influence on Impulse Buying (Y) variable.

Idea Shopping Variable $\left(X_{5}\right)$. The influence of Idea Shopping $\left(X_{5}\right)$ variable to Impulse Buying of online-shopping consumer on Instagram can be seen on the partial correlation coefficient value of 0.514 . It means that contribution (influence) of Idea Shopping $\left(\mathrm{X}_{5}\right)$ to 
Impulse Buying is $5.14 \%$. The value of $t_{\text {count }}$ for this variable is 6.641 , bigger that the value of $t_{t a b l e}$ of 2.009. Then, $t_{\text {count }}>t_{\text {table }}, H_{0}$ is rejected and $H_{1}$ is accepted. In addition, Idea Shopping $\left(X_{5}\right)$ variable has a significant value of 0.000 smaller than $(\alpha) 0.05$. It shows that Idea Shopping $\left(\mathrm{X}_{5}\right)$ variable has positive and significant influence on Impulse Buying $(\mathrm{Y})$ variable.

\section{CONCLUSION AND SUGGESTIONS}

Based on the results of the analysis and discussion in the previous chapter, the conclusion can be drawn as follows:

The following equation was obtained from multiple linear regression analysis:

$$
Y=-22.093+0.1 .579 X_{1}+0.1 .466 X_{2}+0.1 .729 X_{3}+0.254 X_{4}+0.1 .659 X_{5}
$$

From the equation above, it can be seen that Adventure Shopping $\left(X_{1}\right)$, Relaxation Shopping $\left(X_{2}\right)$, Value Shopping $\left(X_{3}\right)$, Social Shopping $\left(X_{4}\right)$ and Idea Shopping $\left(X_{5}\right)$ variables have positive and significant influences on Impulse Buying $(Y)$ of online-shopping consumer on Instagram.

The value of correlation coefficient $(R)$ is 0.619 which means that there is positive and strong relationship--seen from the interpretation table-that is in the position between 0.600 0.799 of Adventure Shopping $\left(X_{1}\right)$, Relaxation Shopping $\left(X_{2}\right)$, Value Shopping $\left(X_{3}\right)$, Social Shopping $\left(\mathrm{X}_{4}\right)$ and Idea Shopping $\left(\mathrm{X}_{5}\right)$ to Impulse Buying $(\mathrm{Y})$ of online-shopping consumer on Instagram.

The determination coefficient value $\left(R^{2}\right)$ shows that Adventure Shopping $\left(X_{1}\right)$, Relaxation Shopping $\left(X_{2}\right)$, Value Shopping $\left(X_{3}\right)$, Social Shopping $\left(X_{4}\right)$ and Idea Shopping $\left(X_{5}\right)$ variables are able to explain the Impulse Buying $(\mathrm{Y})$ of online-shopping consumer on Instagram of $38.4 \%$ while the rest of $61.6 \%$ are influenced by other factors.

From the results of partial testing (t-test), it is concluded that:

- Adventure Shopping $\left(\mathrm{X}_{1}\right)$ variable gives significant influence to Impulse Buying $(\mathrm{Y})$. It can be seen from $t_{\text {count }}>t_{\text {table }}$ or $3.149>2.009$ and it is also supported by significance value $0.001<0.05$.

- Relaxation Shopping $\left(\mathrm{X}_{2}\right)$ variable gives significant influence to Impulse Buying $(\mathrm{Y})$. It can be seen from $t_{\text {count }}>t_{\text {table }}$ or $2.890>2.009$ and it is also supported by significance value $0.005<0.05$

- Value Shopping $\left(\mathrm{X}_{3}\right)$ variable gives significant influence to Impulse Buying $(\mathrm{Y})$. It can be seen from $t_{\text {count }}>t_{\text {table }}$ or $2.142>2.009$ and it is also supported by significance value $0.027<0.05$.

- Social Shopping $\left(\mathrm{X}_{4}\right)$ variable gives significant influence to Impulse Buying $(\mathrm{Y})$. It can be seen from $t_{\text {count }}>t_{\text {table }}$ or $2.548>2.009$ and it is also supported by significance value $0.020<0.05$

- Idea Shopping $\left(X_{5}\right)$ variable gives significant influence to Impulse Buying $(Y)$. It can be seen from $t_{\text {count }}>t_{\text {table }}$ or $6.641>2.009$ and it is also supported by significance value $0.000<0.05$

From the result of simultaneous testing (F-test), it is concluded that $F_{\text {count }}>F_{\text {table }}$ or $12.829>2.669$ with the level of significance of 0.000 indicating that Adventure Shopping $\left(X_{1}\right)$, Relaxation Shopping $\left(X_{2}\right)$, Value Shopping $\left(X_{3}\right)$, Social Shopping $\left(X_{4}\right)$ and Idea Shopping $\left(X_{5}\right)$ variable have influences to Impulse Buying $(Y)$ variable.

To complete the results of this research, the writers provide the following suggestions:

- Online Shopping on Instagram should be able to provide interesting website design and product display visually and creatively in order to give a memorable and pleasant atmosphere for the consumers during shopping. Thus, the consumers get not only the product but also fun and entertainment.

- Offering discounts or cheaper prize on online sales is one strategy in the effort to increase impulse buying of the consumers. In addition, online business must pay attention to the quality of the products. Based on the research results, value shopping significantly influences impulse buying. 
- It is important for the online business to provide the best service, including in answering or responding to questions from consumers, so that the consumers feel satisfied and get information about the products to be purchased. In addition, it increases impulse buying of consumers. Based on research results, social shopping influences impulse buying.

- Online business is required to always make new innovations, follow the latest trends and products so that the consumers visit the website more often with the aim to keep up with the latest trends. In addition, it can encourage someone to be impulsive on online shopping. It is based on the research results that idea shopping influences impulse online.

- From the research results, it is believed that there are many other factors that can influence impulse buying. Therefore, it is suggested for the future researchers to take other variables other than the variables of this research in order to provide better results in describing the appropriate conditions in accordance with the aim of the author.

\section{REFERENCES}

1. Alma, B. (2004). Manajemen Pemasaran dan Pemasaran Jasa. Bandung: Alfabeta.

2. Anderson, J. C., Narus, J. A., \& Narayandas, D. (2009). Business market management: Understanding, creating, and delivering value. Pearson Prentice Hall.

3. Ginting, P dan Situmorang, S.H. (2008) .Filsafat dan Metode Riset. USU Press. Medan.

4. Jain, S. C., \& Haley, G. T. (2009). Marketing planning and strategy. Cincinnati SouthWestern Publishing Company 1985.

5. Kasser, T. E., \& Kanner, A. D. (2004). Psychology and consumer culture: The struggle for a good life in a materialistic world. American Psychological Association.

6. Kotler, P. dan Keller, K.L. (2009). Manajemen Pemasaran, Edisi B Jilid 1 Terjemahan oleh Benyamin Molan. Jakarta: Erlangga.

7. Kotler, P., \& Armstrong, G. (1999). Principles of marketing,-8th ed-Prentice Hall. New Jersey.

8. Loudon, D. L., \& Della Bitta, A. J. (1993). Consumer behaviour. Concepts and Applications,(4th Ed.) New York: McGraw-Hill.

9. Paramitha, A. O., Arifin, Z., Sunarti (2014). Pengaruh Nilai Belanja Hedonis Terhadap Pembelian Impulsif Pada Toko Online Dengan Emosi Positif Sebagai Variabel Perantara.Jurnal Administrasi Bisnis, 1-9

10. Paramitha, A. O., Arifin, Z., Sunarti (2014). Pengaruh Nilai Belanja Hedonis Terhadap Pembelian Impulsif Pada Toko Online Dengan Emosi Positif Sebagai Variabel Perantara.Jurnal Administrasi Bisnis, 1-9

11. Rook, D. W., \& Fisher, R. J. (1995). Normative influences on impulsive buying behavior. Journal of consumer research, 22(3), 305-313.

12. Srivastava, S., dan Kumar, M. (2013). Evaluating Effective Situational Factors on Consumer Impulsif Buying.International Journal of Applied Research \& Studies, 2, 1-11.

13. Utami, C. W. (2010). Manajemen Ritel: Strategi dan Implementasi Operasional Bisnis Ritel Modern dilndonesia edisi 2. Jakarta: Salemba Empat.

14. Utami, C. W. (2010). Manajemen Ritel: Strategi dan Implementasi Operasional Bisnis Ritel Modern dilndonesia edisi 2. Jakarta: Salemba Empat

15. Wilson, A., Zeithaml, V. A., Bitner, M. J., \& Gremler, D. D. (2012). Services marketing: Integrating customer focus across the firm. McGraw Hill. 